\title{
Reflecting on Jeffrey Brooks' The Firebird and the Fox: The Unusual but True Adventures of a Soviet Agronomist
}

\author{
2nd Contribution to the Forum about The Firebird and the Fox: Russian \\ Culture under Tsars and Bolsheviks by Jeffrey Brooks
}

\author{
Muireann Maguire \\ Senior Lecturer in Russian, College of Humanities, Faculty of Modern \\ Languages and Cultures, University of Exeter, Exeter, UK \\ muireann.maguire@exeter.ac.uk
}

Jeffrey Brooks. The Firebird and the Fox: Russian Culture under Tsars and Bolsheviks. Cambridge: Cambridge University Press, 2019. xvii, 33 o pp., Images, Endnotes, Index. Is BN 978-1-108-48446-6

\begin{abstract}
This essay responds to Jeffrey Brooks' 2020 monograph The Firebird and the Fox, drawing attention to Brooks' emphasis on a set of cultural symbols persistent during the historical period he surveys, and on the social activism which he identifies with leading Russian cultural figures such as Tolstoi and Chekhov. In support of Brooks' argument, I present the example of Aleksandr Chaianov (1888-1937), a specialist in agronomy and amateur writer whose reputation as a driver of early Soviet agricultural policy was overshadowed by his arrest in 1930 and subsequent exile and execution. Chaianov's social activism, as expressed in his short fiction and historical essays, took the form of reminding his readers about the cultural continuities between Russia's past, present, and future.
\end{abstract}

\section{Keywords}

Jeffrey Brooks - Russian culture - Russian literature - The Firebird and the Fox Aleksandr Chaianov - Soviet agronomy 
The Firebird and the Fox is a bold and useful book. Useful, because it discusses Russian history and culture (including many well-known figures, with their achievements) in a simple, coherent, and eminently teachable way. Bold, because its author, Jeffrey Brooks, is unafraid to organize the historical period between $185^{\circ}$ and 1950 into a continuum, to defend those dates as logical start and end points for his analysis, and to argue for the persistence and interdependence of certain cultural symbols and symbolic characters (such as the firebird and the fox; the not always holy fool; and my personal favourite, the trickster) during this time. This is not to say that Brooks' organization is in any way incoherent or unreasonable. But historians love to collapse historical time into ever-more-discrete mini-epochs, five-year-plans of unitary evolution; and the nineteenth and twentieth centuries offer plenty of these. By taking the long view and looking for resonances and continuities rather than focusing on erratic or divergent phenomena, Brooks bucks a scholarly trend. Yet even within his sensible century-long timeline, he delineates three distinct time zones: the forty years of maturing cultural confidence, from 1850 to 189 ; a quarter-century of artistic and political experimentation, leading up to 1916; and the scatter plot of artistic endeavour versus state consolidation between 1917 and 1950. The great achievement of The Firebird and the Fox is to show that many of the same cultural imperatives, dialogues, mediators and even personalities retained their influence and significance throughout all three periods. Finding continuity of any sort amid the earthquakes and vortices of modern Russian history, as Brooks does in this monograph, is a radical act of common sense.

For me, the most important messages of Brooks' book are twofold: firstly, that Russian culture is a continuous and accumulative process; and secondly, that Russian writers and artists are perennially engaged, not just with creativity and self-invention, but with world-creation. They feed back to the society that sustains them, enriching and re-inventing it. The first insight may come as a relief to students, since it is easier to treat cultural history as a system of layers than as an archipelago of random developments; the second, as rather more of a surprise. Russian culture is self-referential, and in dialogue with its recent past to a degree unprecedented in modern Europe. Even innovation typically establishes itself as a renewal, rather than a rebuttal, of the nineteenth-century canon; aesthetic departures are viewed through the lens of past triumphs. Critics compared the early fiction of Zakhar Prilepin, the soldier-turned-littérateur infamous for his extremist Russian nationalist opinions, to Lev Tolstoi's early work; Prilepin's Chechnya was seen to refract Tolstoi's Crimea. These days Prilepin likes to compare his politics rather than his talents with Tolstoi's, suggesting that the latter would have fought for the Donetsk People's Republic against 
Ukrainian government forces. ${ }^{1}$ The contemporary director Iuri Butusov's postmodernist production of Chaika [The Seagull] (2011) with the Satirikon Theatre may drastically re-construct Chekhov's play, even adding characters and set pieces that the playwright, however ribald his imagination, would never have envisaged on stage; and yet the words and the message of the Satirikon's Seagull are still recognizably Chekhovian (albeit with zombies). In both cases, radical twenty-first century art is refracted through the mirror of nineteenthcentury writing. The Firebird and the Fox stops in 1950, but even as late as the 193os Brooks reveals similar examples of cultural continuity: the writer Daniil Kharms in his absurdist children's stories and the composer Sergei Prokofiev, in his symphony for children Petia $i$ volk [Peter and the Wolf] (1936), both tap a tradition of folkloric morality and helpful animals that reaches back to the Symbolist-era fairytales of Ivan Bilibin, and earlier still to Petr Ershov's 1834 tale Konek-Gorbunok [The Little Humpbacked Horse]. Meanwhile, Anton Platonov's ontological fiction of the 1920 s and 193os echoes Fedor Dostoevskii's efforts to define an ethically meaningful life in the previous century. Vasilii Grossman's epic Second World War dilogy, Za pravoe delo [For a Just Cause] (1952; recently published in English translation as Stalingrad) and Zhizn' i sud'ba [Life and Fate] (1959), is in dialogue with Tolstoi's War and Peace. Like some absurd hybrid of Gogol's and Kharms' imaginations, Russian literature is constantly digesting itself.

The surprising element in Brooks' study, especially for students accustomed to regarding culture as an elite activity, is his emphasis on the activism of most Russian cultural figures. Examples range from Marc Chagall 'mobiliz[ing] the housepainters of Vitebsk to plaster the city with his brightly colored cows and horses' (Brooks, 181) in order to commemorate the first anniversary of the 1917 October Revolution, to the Peredvizhniki artists' movement of the 187os, a group of landscape and portrait artists determined to bring their thenunfashionable art to the Russian people by exhibiting their art widely at their own expense. This kind of impetus is exhortative and performative, not to be confused with self-publicity: these artists and the writers struggled to publish, distribute, or display much of their work in frustrating conditions imposed by censorship, poverty, persecution, or any combination of the three. Think of how the now-venerable samizdat tradition emerged as a lifeline for independent Soviet writers and readers in the decades between the end of The Firebird

1 Julie Fedor, “Spinning Russia's 21st Century Wars: Zakhar Prilepin and his 'Literary Spetsnaz,", The RUSI Journal, 163, no. 6 (2018): 18-27, here, 25. DOI: 10.1080/03071847.2018.1562015. 
and the Fox's survey and the fall of the Soviet Union. ${ }^{2}$ Nor has this urge disappeared in contemporary Russia's somewhat more liberal society; wherever censorship makes standard pathways impossible, writers create their own audiences - from among their own ranks, if necessary. A recent example is the F-writing collective, organized by the poet Lida Iusupova, which exists to enable the reading, translation and circulation of LGBTQ literature (heavily censored by recent legislation against so-called gay propaganda). ${ }^{3}$ Historically Russian writers have demanded social or political change by decrying a bad situation (Ivan Turgenev's tales of mistreated serfs; Avdot'ia Panaeva's novels of abused women); ${ }^{4}$ by picturing better alternatives (Nikolai Chernyshevskii's dream utopia in Chto delat'? [What Is To Be Done] (1863); Fedor Gladkov's revived factory collective in Tsement [Cement] (1925)); and even by donating literary profits to a good cause. For instance, the well-known nineteenth-century authors Nikolai Nekrasov, Nikolai Leskov and Mikhail Saltykov-Shchedrin were among well over a dozen writers who supplied stories for a special anthology, Skladchina [Pot-luck], produced in two volumes in $1873^{-4}$ to raise money for famine sufferers in the Samara region. Finally, some writers live the change through their own choices (there are too many examples to count).

Brooks shares several high-profile examples of such civic engagement from the late nineteenth and early twentieth centuries, primarily in Chapter Five, 'The Writer as Civic Actor'. We learn how Tolstoi channelled the profits from his last full-length novel Voskresen'e [Resurrection] (1899) towards the emigration of the Dukhobors, and, how during the terrible Volga region famine of the 1890 s, Chekhov exploited his publications, his medical skills, and his organizational abilities to provide both financial and direct, pragmatic assistance to the worst-affected. Nor were these incidents exceptional behaviour on the part of either writer; Tolstoi had raised funds for and reported the condition of those same drought-ravaged farmers of the Samara region earlier in 1873 (he had recently purchased an estate there). Because Tolstoi's article describing the Samara drought appeared in a Moscow newspaper later that year, a huge

2 For the latest scholarship on samizdat, see Josephine von Zitzewitz, The Culture of Samizdat: Literature and Underground Networks in the Late Soviet Union (London: Bloomsbury Academic, 2021). Another interesting analysis of the emergence of a distinctive culture under forbiddingly restricted conditions (here, the Soviet prison camps inside the Arctic Circle) is found in Andrea Gullotta, Intellectual Life and Literature at Solovki 1923-1930: The Paris of the Northern Concentration Camps (Cambridge, UK: Legenda, 2018).

3 For more on this collective, see the anthology FLetter: New Russian Feminist Poetry, ed. Galina Rymbu, Eugene Ostashevsky, and Ainsley Morse (New York, NY: isolarii, 2020).

4 For a discussion of Panaeva's fiction, see Margarita Vaysman, "A Woman's Lot: Realism and Gendered Narration in Russian Women's Writing of the 186os," The Russian Review, 80, no. 2 (April 2021): 229-245. 
national relief effort, including the Skladchina anthology, was launched. In Bob Blaisdell's words, 'Russia learned about the famine [...] and a heap of money was donated, some of it actually directed to the particular families that Tolstoi had mentioned'. 5 After purchasing his estate at Melikhovo, near Moscow, in the 189os, Chekhov continued to provide medical services to the local peasantry and to sit on the zemstvo council throughout the seven years that he lived there. Nor was charitable activity unique to Russia's most high-profile writers: the novelist and short-story writer Vladimir Korolenko (1853-1921), for example, was also strongly motivated to help the disadvantaged. Korolenko cameos twice in The Firebird and the Fox, as a quiet hero who chose, in 1881, political exile over personal disloyalty. Both Korolenko and Chekhov resigned from the Russian Academy of Sciences in 1902, when Maksim Gorky was expelled from the organization. Like his friend Chekhov, Korolenko exerted all his professional skills - not merely his talents as a writer of fiction - to improve Russian society. Formally trained as a specialist in forestry, he travelled over much of Siberia, using his skills as a journalist and even as a legal advocate to protect provincial communities and ethnic groups from the government's abusive treatment of their rights and properties. The Firebird and the Fox reminds us that Russian writers succeeded in expressing both personal ethical principles and public charity through a combination of philanthropy, propaganda, and the direct gift of their professional skills. Moreover, the creative expression of these aims relies upon symbols and subtexts that have been continuously recycled by Russia's cultural elites since their rediscovery of folk literature and art in the eighteenth century.

As an amplification of Brooks' insight, and also as a kind of coda to The Firebird and the Fox's many descriptions of socially engaged artists and writers, I would like to offer the life of Aleksandr Vasil'evich Chaianov, a Soviet-era economist, university professor, and gifted literary amateur. Chaianov was born into a bourgeois family in 1888 just before the end of Brooks' first subsection; the Silver Age was well underway, and Imperial social liberalization had reached its zenith. Chaianov's father retired from the family's successful textile business in the provinces in 1885 , aged thirty-nine, and moved to the Moscow suburbs to live off his investments; Chaianov's mother belonged to the first generation of women students to graduate from the Petrovskii Academy of Agriculture and Forestry, or Petrovka (where Korolenko had also studied, briefly, in the mid-187os). Chaianov would follow in his mother's footsteps, graduating from the same Petrovka Academy, now renamed the Moscow

5 Bob Blaisdell, Creating Anna Karenina: Tolstoy and the Birth of Literature's Most Enigmatic Heroine (New York, NY: Pegasus Books, 2020), 73. 
Institute of Agriculture, in 1910. Upon graduation, he immediately began teaching classes on the history and geography of Russian agriculture, at both the new Shaniavskii People's University and the Moscow Institute of Commerce. Numerous publications on Russian agrarian practice made him internationally celebrated, and from 1917 onwards he participated in many state committees which aimed to overhaul Soviet agricultural practice and management. In this capacity, Chaianov represented the Soviet Union at conferences in several European countries in 1922 and 1923. In 1918, he was appointed professor at the Petrovka (soon to be renamed the Timiriazev Academy in honour of the botanist Kliment Timiriazev), a post he retained until his arrest on charges of conspiracy in 1930. After four years of imprisonment, he was exiled to Alma-Ata in Kazakhstan, where he began teaching again. Chaianov was re-arrested and shot in 1937 at the height of the Stalinist purges which destroyed so many other talents, shaped by the ideals of the nineteenth century and inspired by the ordeals of the early twentieth. ${ }^{6}$

Historians remember Chaianov's important contribution to Soviet agronomy, not only as a researcher but as an organizer: he was President of the People's Commissariat for Agriculture between 1921 and 1923, and Lenin consulted him personally numerous times. And yet even in 1918, when he began advising Soviet governmental committees in addition to his teaching, Chaianov somehow found time to write and publish his enchanting, Hoffmannesque fantasies, the last of which appeared in 1928 . He was well-connected nationally and internationally (his extensive overseas networks no doubt led to later accusations of spying). His friends from the Petrovka included scientists like Nikolai Vavilov (1887-1943; a celebrated geneticist who would also die in Stalin's purges) but also various Symbolist-era literary figures and artists, most famously the author, art historian and later émigré, Pavel Muratov (1881-1950; whose strange fate was to die in Waterford, Ireland, as the house guest of British scholar William Allen). Literary scholars will recall the slightly didactic science-fiction novella Chaianov published pseudonymously in 1920 (Puteshestvie moego brata Alekseiia $v$ stranu krest'ianskoi utopii [The Journey of My Brother Aleksei Into The Land of Peasant Utopia]); and Bulgakov specialists, at least, cherish the five playful Gothic-fantastic short stories which Chaianov composed during this decade, one of which ("Venediktov", 1921) probably influenced Mikhail Bulgakov's Master i Margarita [Master and Margarita] (1940).

6 The biographical details on Chaianov given here derive from two sources: V.B. Murav'ev, "Tvorets Moskovskoi gofmaniady," in A.V. Chaianov, Moskovskaia gofmaniada, ed. E.A. Tonchu (Moscow: Tonchu, 2006), 275-302; and V.A. Chaianov, "Aleksandr Vasil'evich Chaianov," in A.V. Chaianov, Izbrannoe: Stat'i o Moskve. Pis'ma (19o9-1936), ed. S.B. Frolova (Moscow: Tonchu, 2008), 276-317. 
All five of the short stories reproduce familiar motifs from the Golden Age tradition of Pushkin and Gogol, overlaid with a strong Symbolist focus on magic, demons, and self-delusion. Trickster characters figure in almost every one of Chaianov's tales, as do plots of travel (in which the hero undertakes an elliptical flight or quest, often through Western Europe, but always returning to Moscow - as did Chaianov himself in the early 1920s). The eponymous antihero of "Venediktov" clearly belongs to the lineage of the 'superfluous man' type invented by Byron and Russianized by Lermontov, Pushkin and Turgenev. In "Neobychainye, no istinnye prikliucheniia grafa Fedora Mikhailovicha Buturlina" ["The Unusual but True Adventures of Count Fedor Mikhailovich Buturlin"] (1924), which Chaianov considered his masterpiece, the hero is a naïve young nobleman easily tricked in a card game with an elderly sorcerer (who turns out to be the historical Count Jacob Bruce, since Chaianov cannot resist a disguised history lesson). ${ }^{7}$

Aleksandr Chaianov's life, spanning the middle period of Brooks' century, exemplified Brooks' now-familiar patterns of intertextual dialogue and social engagement. Chaianov devoted his energies and his professional skills to the new state, and in particular, to modernizing and rationalizing the production of its basic needs: food and linen. At the same, while the ethos of Soviet Communism demanded a fixed, forward-focused perspective from its agents, Chaianov quietly insisted on keeping one eye on the past. This deliberately rear-facing focus is evident in the richly evocative historical context of his novellas:

This was the time when Paraskova Zhemchugova captured hearts at the Kuskovskii Theatre, and the household troupes of twenty Moscow nobles vainly vied with her fame; when Golovkin, Teorez and Chefroli filled the rising palaces of famous Moscow names with canvases by the great masters, born under the burning sun of Italy and in the ghostly fogs of Amsterdam; and Novikov and Schwartz, in the hush of Masonic lodges, contemplated their plans for the tasks of the Moscow Martinists. ${ }^{8}$

In this paragraph, which sketches the background for the eponymous Count Fedor Buturlin's unusual adventures in eighteenth-century Moscow, Chaianov mentions a number of exotic historical figures, beginning with the serf actress

7 For more on the symbolic role of the alchemist in Chaianov's story, see Muireann Maguire, "The Wizard in the Tower: Iakov Brius and the Representation of Alchemists in Russian Literature," The Slavonic and East European Review, 90, no. 3 (July 2012), 401-42, here 419-21. DOI: https://doi.org/10.5699/slaveasteurorev2.90.3.0401.

8 A.V. Chaianov, "Neobychainye, no istinnye prikliucheniia grafa Fedora Mikhailovicha Buturlina,", in A.V. Chaianov, Moskovskaia gofmaniada, ed. E.A. Tonchu (Moscow: Tonchu, 2006), 138-85, here 139. All translations from Russian are my own. 
Praskov'ia Zhemchugova (1768-1803), who married Count Nikolai Sheremetev (Kuskovo was one of his Moscow estates). Count Petr Golovkin was a wellknown art collector of the late eighteenth century, while Teorez and Chefroli were both antiques dealers active in the Russian capital at that time. The journalist and editor Nikolai Novikov (1744-1818), and the professor and author Ivan Schvartz, who died in 1784, were both active figures in the Russian Enlightenment; both were Freemasons. The Martinists were an esoteric Christian sect, relatively widespread in Russia, with strong links to Masonry. Chaianov's wealth of obscure references challenges the reader's historical knowledge: but in doing so, it conjures up an image of an outwards-looking, multi-cultural, multi-ethnic nation, interpenetrated by multiple cultural fashions and philosophical trends. Unlike his younger contemporary Mikhail Zoshchenko (1894-1958), whose relative success under Soviet literary conditions Brooks analyses concisely and deftly, Chaianov rejected contemporary settings and everyman characters. Nor did he, as Zoshchenko does, screen his opinions behind a protective filter of skaz narration: the note of elegiac nostalgia characteristic of Chaianov's narrators clearly evokes the author's own regret for a more colourful, richly textured past. ${ }^{9}$

Chaianov's short historical essays (half a dozen of which were published between 1918 and 1925) most concisely express his mission to teach ordinary Russians to appreciate their past. One of the earliest such essays. "Kooperatsiia i khudozhestvennaia kul'tura Rossii" ["Co-operation and Russia's Artistic Culture"] (1919), communicated both Chaianov's delight at increased public access to museums under Soviet rule and his concern that treasures of Russian art were being trafficked abroad. "In recent years it has sufficed to glance own Lavrushinskii Alley, into the halls of the Tret'iakov Gallery, and to see the crowd in its varied costumes and social categories, hushed before the canvases of Surikov, Bastien-Lepage and Repin, attentively gazing at the fairy-tale visions of Vrubel', Carrière and Borisov-Muratov, to understand how wide are the circles of our people [narod] nourishing themselves with this treasure of the human spirit," Chaianov wrote, before urging on his readers the importance of using the new nationalized banks and workers' co-operatives to establish a public fund that would prevent the loss of these national "treasures" from Russian museums to collectors abroad. ${ }^{10}$ He pointed to successes already

9 Chaianov's position as a Gothic-fantastic writer in the so-called 'Bulgakov cohort' of Russian Hoffmannism is discussed in Muireann Maguire, Stalin's Ghosts: Gothic Themes in Early Soviet Literature (Berlin: Peter Lang, 2012), 257-71.

10 A.V. Chaianov, "Kooperatsiia i khudozhestvennaia kul'tura Rossii," in Chaianov, Izbrannoe: Stat'i o Moskve. Pis'ma (19o9-1936), ed. Frolova, 143-7, here 143. 
achieved by a committee in which his friend Muratov participated. Citing the inscription on the lintel above the door of the Rumiantsev Museum, Moscow's first public museum (which, ironically, the Soviet government would close in 1924), Chaianov argued that 'the interests of a 'noble enlightenment' must not be foreign to a democratic Russia".11

These essays show that Chaianov was no passive participant, nor a victim, in the social and political upheavals he witnessed: instead, he consciously observed the changes overtaking Russian society and tried to temper the more visible ones - the reinvention of the urban landscape - by revisiting superseded or obscured architectural texts of the past. This topographical (and toponymic) awareness is most evident in Chaianov's short historical guides, aimed at a general audience. In his "Istoriia Miiusskoi Ploshchadi: K istorii universiteta imeni A.L. Shaniavskogo" ["A History of Miiuskaia Square: Towards a History of Shaniavskii University"] (1918), Chaianov notes that an entire sector of northern Moscow near modern Novosloboskaia, formerly an uncultivated semi-wilderness used for storing and trading logs, had been recently transformed by city planners. Since 1908, a new university (the Shaniavskii People's University, where Chaianov himself had taught) and even a new cathedral (demolished by the Bolsheviks in the 1930s) had been constructed on the site. He invited his readers to empathize with hypothetical Muscovites who might have slept Cinderella-like from the "cannons of December 1905" through to the "cannons of October 1917," waking to find former wilderness reconfigured as a gracious public square. (This rhetorical reduction of the Revolutionary period to a kind of transient fugue, easily overlooked, was hardly politically astute in 1918). Chaianov's evocation of pre-revolutionary Miiusskaia Square appeals to several senses simultaneously: "Ten years ago on the very spot where the walls of Shaniavskii University stand today, impenetrable puddles of filth perpetually lingered, logs from the sawmills lay around in heaps and a little crooked chapel kept the secret of its origins." ${ }^{12}$ But Chaianov quickly led readers into the district's more remote past, reproducing antique maps of the city to illustrate his historical narrative. Since little was recorded about the wasteland that would become Miiusskaia Square, he described instead the people and phenomena which literally passed it by: the ill-fated Polish princess Marina Mnishek (1588-1614) en route to her Orthodox wedding ceremony with the first False Dmitrii in 16o6; the Napoleonic Great Fire of Moscow in 1812 that blazed all the

11 Chaianov, "Kooperatsiia i khudozhestvennaia kul'tura Rossii," 147.

12 A.V. Chaianov, "Istoriia Miiusskoi Ploshchadi: K istorii universiteta imeni A.L. Shaniavskogo," in Chaianov, Izbrannoe: Stat'i o Moskve. Pis'ma (1909-1936), ed. Frolova, 7-23, here 7 . 
way to the Lesnoi riad [Forest Row], indirectly stimulating the reconstruction project that would eventually create the contemporary city. Only on the subject of the square's future under Communism, Chaianov proved unexpectedly mute: "From this moment [1915], the modern period for the square begins, and the accidental historian sets aside his quill."13

The most substantial essay, "Petrovsko-Razumovskoe v ego proshlom i nastoiashchem: Putevoditel' no Timiriazevskoi sel'skokhoziaistvennoi akademii” ["The Petrovsko-Razumovskoe Past and Present: A Guide to the Timiriazev Academy of Agricultural Science"] (1925), divided into six sections, concerns a subject close to Chaianov's heart, since he was at different times both student at and director of this particular academy. Typically, Chaianov was expansive about the site's aristocratic past, as it evolved from a modest property on the estate of the Shuiskii family to one of the major possessions of the wealthy Razumovskiis. He sketched how Count Kirill Grigor'evich Razumovskii (1724-1803) and his son Lev transformed the estate buildings into a palace filled with artworks and antiques; here, although Chaianov emphasized the desperate inequalities between rich and poor (which "we, the inhabitants of Soviet Moscow, can imagine only with the greatest difficulty"), his attention (if not his sympathies) appears to remain with the wealth and "blesk" ["glitter"] of Elizaveta I's court. ${ }^{14}$ In later sections of the essay, Chaianov describes the Academy's teaching programme, before listing possible strolls through the park and surrounds of the Academy, each described in loving historical detail. He does not fail to remind us that I.I. Ivanov, the student murdered by the terrorist Sergei Nechaev in 1869, was enrolled at the Academy. ${ }^{15}$ This infamous incident inspired Dostoevskii's novel Besy [Demons] (1872). Chaianov's commentary on the Petrovsko-Razumovskii estate concluded on a note of concern reminiscent of Chekhov's ecological consciousness, warning that the natural world "requires protection and careful attitudes towards it."16

The same might have been said of Chaianov's own legacy. Like the alchemist of legend, a recurrent character in nineteenth-century Russian literature, Chaianov's prose transmuted Russia's past into a gilded and exotic memory palace. And also like another cultural outsider in Soviet Russia, the writer Sigizmund Krzhizhanovskii (1887-1950), Chaianov's fascination with the past was both unfashionable and dangerous in his own time. Aleksandr Chaianov's

\footnotetext{
13 Chaianov, "Istoriia Miiusskoi Ploshchadi", 23.

14 A.V. Chaianov, "Petrovsko-Razumovskoe v ego proshlom i nastoiashchem: Putevoditel' no Timiriazevskoi sel'skokhoziaistvennoi akademii," in Chaianov, Izbrannoe: Stat'i o Moskve. Pis'ma (1909-1936), ed. Frolova, 24-107, here 44.

15 Chaianov, "Petrovsko-Razumovskoe v ego proshlom i nastoiashchem," 51.

16 Chaianov, "Petrovsko-Razumovskoe v ego proshlom i nastoiashchem," 107.
} 
nonfiction prose reclaimed Moscow's architectural heritage and historical collections; his fiction brought these to life, in fantasies rich with Freemasons, card-sharpers, itinerant mermaids and dissipated oligarchs. His own reputation was ultimately rehabilitated fifty years after his death; and thanks to historians and literary scholars, both aspects of Chaianov's achievements in agronomy and in literature - are finally coming to light again. Studies like The Firebird and the Fox aid this process of cultural self-discovery and restoration of the canon, by demonstrating that untimely, forgotten figures such as Chaianov were not, in fact, freaks or outliers. Like the neoclassical pediments and medieval street names that unobtrusively delineate the buildings and thoroughfares of post-Soviet Moscow, his works hint at the hidden architecture of a cultural continuity which pre-existed, and survived, the historical turbulence of the twentieth century. 